\title{
Hubungan antara Status Gizi dengan Gingivitis pada Mahasiswa Program Studi Pendidikan Dokter Gigi Universitas Sam Ratulangi
}

\author{
${ }^{1}$ Fenti Hanifah \\ ${ }^{2}$ Shirley E. S. Kawengian \\ ${ }^{1}$ Elita Tambunan \\ ${ }^{1}$ Program Studi Pendidikan Dokter Gigi Fakultas Kedokteran \\ ${ }^{2}$ Bagian Ilmu Gizi Fakultas Kedokteran \\ Universitas Sam Ratulangi Manado \\ Email: fentihanifah32@gmail.com
}

\begin{abstract}
Gingivitis is an inflammation process of gingiva caused by accumulation of biofilm on plaques around the margin of gingiva as well as an inflammation response against bacteria. Nutritional status is affected by macro and micronutrient intake. Poor nutritional status can cause abnormality of function and structure of oral soft tissue resulting in increased plaque forming which leads to the occurence of gingivitis. This study was aimed to obtain the relationship between nutritional status and the occurence of gingivitis. This was an analytical study using a cross-sectional design. Samples were obtained by using total sampling method. There were 77 students as samples. The nutritional status was measured by using body mass index (BMI), and examination of oral cavity was performed to check the occurence of gingivitis. The result showed that $46.8 \%$ of students had gingivitis. The nutritional status of the students based on IMT were as follows: $19.5 \%$ were categorized as underweight, $65 \%$ as normal weight, $9 \%$ as overweight, and $6.5 \%$ as obese. The bivariate analysis using the Chisquare test showed a $P$ value of $0.000(<0.05)$. Conclusion: There was a significant relationship between the nutritional status and gingivitis in students of Dentistry Program, Sam Ratulangi University.

Keywords: nutritional status, gingivitis
\end{abstract}

\begin{abstract}
Abstrak: Gingivitis merupakan reaksi inflamasi dari gingiva yang disebabkan oleh akumulasi biofilm pada plak di sekitar margin gingiva dan respon peradangan terhadap bakteri. Status gizi dipengaruhi oleh asupan gizi makronutrien dan mikronutrien yang seimbang. Gizi kurang dapat menyebabkan gangguan fungsi dan struktur jaringan lunak mulut sehingga pembentukan plak meningkat yang menjadi penyebab awal gingivitis. Penelitian ini betujuan untuk mengetahui hubungan antara status gizi dengan gingivitis. Jenis penelitian ialah analitik dengan desain potong lintang. Pengambilan sampel menggunakan total populasi sebanyak 77 mahasiswa Program Studi Pendidikan Dokter Gigi Universitas Sam Ratulangi. Status gizi diukur menggunakan rumus perhitungan IMT dan pemeriksaan rongga mulut dilakukan untuk melihat ada tidaknya gingivitis. Hasil penelitian menunjukkan 46,8\% mahasiswa mengalami gingivitis. Penentuan status gizi berdasarkan IMT mendapatkan sampel kategori kurus $(19,5 \%)$, normal $(65 \%)$, berat badan lebih $(9 \%)$, dan obesitas $(6,5 \%)$. Hasil analisis bivariat menggunakan uji Chi-square menunjukkan nilai $P=0,000(0,000<0,05)$. Simpulan: Terdapat hubungan bermakna antara status gizi dengan gingivitis pada mahasiswa Program Studi Pendidikan Dokter Gigi Universitas Sam Ratulangi.
\end{abstract}

Kata kunci: status gizi, gingivitis

Kelaparan masih menjadi beban dunia sampai dengan akhir abad 20 ini. Dunia meresponnya dengan menyepakati suatu pertemuan pada September tahun 2000 
yang diikuti oleh 189 negara dengan mengeluarkan deklarasi yang dikenal dengan The Millenium Development Goals (MDG's) yang berakhir pada tahun 2015. Dengan berakhirnya era MDGs, maka saat ini telah memasuki era sustainable development goals (SDGs). ${ }^{1}$ Salah satu goals dari SDGs ialah "tidak ada kelaparan" (zero hunger), yaitu mengakhiri kelaparan dan segala bentuk kekurangan gizi tahun 2030 serta menjamin akses universal dengan kecukupan makanan bergizi sepanjang tahun. $^{2}$

Berdasarkan data dari Riset Kesehatan Dasar (Riskesdas) pada tahun 2013, prevalensi penduduk dewasa kurus $8,7 \%$, normal $37,6 \%$, berat badan lebih $13,5 \%$, dan obesitas 15,4\%. Prevalensi obesitas penduduk laki-laki dewasa ( $>18$ tahun) pada tahun 2013 sebanyak 19,7\%, lebih tinggi dari tahun $2007(13,9 \%)$ dan tahun 2010 (7,8\%). Prevalensi obesitas pada perempuan dewasa (>18 tahun) sebesar $32,9 \%$, naik $18,1 \%$ dari tahun 2007 $(13,9 \%)$, dan $17,5 \%$ dari tahun 2010 $(15,5 \%)$. Kecenderungan status gizi dewasa menurut IMT tidak terlalu banyak perubahan, status gizi normal dari tahun 2007 ke tahun $2013(<40 \%){ }^{3}$

Asupan zat gizi sangat penting dan mendasar dalam kehidupan manusia yang berfungsi sebagai penghasil energi, pembangunan, memelihara dan mengatur proses kehidupan. Pada saat ini Indonesia mengalami masalah gizi ganda yaitu masalah kekurangan gizi dan kelebihan gizi yang berdampak pada penurunan kualitas sumber daya manusia (SDM) suatu bangsa dan salah satu penyebab utama kematian di Indonesia. ${ }^{4}$ Kekurangan gizi terjadi akibat asupan gizi dibawah kebutuhan, sedangkan kelebihan gizi timbul karena asupan gizi melebihi kebutuhan. ${ }^{5}$

Gigi dan mulut merupakan tempat awal masuknya kuman dan bakteri yang dapat mengganggu kesehatan organ tubuh lainnya, namun kesehatan gigi dan mulut sering kali dijadikan prioritas yang kesekian bagi sebagian orang. Hasil Riskesdas tahun 2013 Kementerian Kesehatan RI menunjukkan bahwa $63 \%$ penduduk Indonesia menderita penyakit gigi dan mulut meliputi karies gigi dan penyakit jaringan periodontal. ${ }^{6}$ Penyakit periodontal memiliki prevalensi cukup tinggi yang banyak diderita oleh manusia hampir diseluruh dunia dan mencapai $50 \%$ dari jumlah populasi dewasa. Di Indonesia penyakit periodontal menduduki urutan kedua utama yang masih merupakan masalah di masyarakat dengan prevalensi penyakit periodontal usia semua kelompok usia di Indonesia sebesar $96,58 \%{ }^{7}$ Penyakit periodontal yang paling sering dijumpai yakni keradangan gingiva atau gingivitis. ${ }^{8}$

Gingivitis merupakan reaksi inflamasi dari gingiva yang disebabkan oleh akumulasi biofilm pada plak disekitar margin gingiva dan respon peradangan terhadap bakteri. Gejala klinis gingivitis ditandai dengan perubahan warna, perubahan bentuk, perubahan konsistensi, perubahan tekstur, dan pendarahan pada gingiva. ${ }^{9}$

Status gizi dipengaruhi oleh asupan gizi makronutrien dan mikronutrien yang seimbang. Akibat gizi kurang dalam rongga mulut yaitu gangguan fungsi dan struktur jaringan lunak mulut, terutama pada ujung bibir, lidah, palatum, dan pada gigi sehingga pertumbuhan mikroba dalam celah gingiva meningkat oleh terjadinya penguraian makanan di sekitar gigi. ${ }^{10}$

Penelitian yang dilakukan oleh Suhail dan Al-Obaidi di Iraq pada tahun 2014 menyatakan bahwa status gizi memiliki hubungan bermakna dengan kondisi periodontal. ${ }^{11}$ Survei awal pada mahasiswa Program Studi Pendidikan Dokter Gigi (PSPDG) Universitas Sam Ratulangi mendapatkan beberapa mahasiswa dengan kondisi status gizi kurus, normal, berat badan lebih dan obesitas tetapi belum pernah dilakukan penelitian tentang gingivitis sebelumnya. Penelitian ini bertujuan untuk mengetahui hubungan antara status gizi dengan gingivitis pada mahasiswa PSPDG Universitas Sam Ratulangi.

\section{METODE PENELITIAN}

Jenis penelitian ini ialah analitik dengan desain potong lintang. Penelitian ini dilaksanakan di Program Studi Pendidikan 
Dokter Gigi Universitas Sam Ratulangi pada bulan Maret - April 2018.

Populasi dalam penelitian ini ialah semua mahasiswa angkatan 2014-2017 di PSPDG Universitas Sam Ratulangi berdasarkan survei awal sebanyak 90 orang. Metode pengambilan sampel yang digunakan ialah total populasi yang memenuhi kriteria inklusi sebanyak 77 orang.

Pengumpulan data dilakukan dengan pemeriksaan langsung terhadap subjek penelitian. Data yang dikumpulkan yakni nama lengkap, umur, dan jenis kelamin, status gizi dan hasil pemeriksaan gingivitis.

Mahasiswa sebelumnya diberikan informed consent, kemudian dilakukan pengukuran berat badan menggunakan alat timbangan badan dan pengukuran tinggi badan menggunakan stature meter. Hasil ukurnya dikategorikan menjadi empat kategori yaitu kurus $<18,5$; normal $\geq 18,5$ $<24,9$; berat badan lebih $\geq 25,0-<27,0$; dan obesitas $\geq 27,0$. Dilanjutkan dengan pemeriksaan rongga mulut dengan menggunakan alat kaca mulut dengan membedakan yang mengalami gingivitis diberi tanda $(\sqrt{ })$, yang tidak mengalami gingivitis diberi tanda $(\mathrm{X})$ pada lembar pemeriksaan.

Pengolahan data dilakukan menggunakan Statistical Product and Service Solution (SPSS). Analisis univariat digunakan untuk mendeskripsikan masing-masing variabel serta disajikan dalam bentuk tabel. Analisis bivariat menggunakan uji statistik Chi-square untuk menguji hubungan antara status gizi dengan gingivitis.

\section{HASIL PENELITIAN}

Penelitian ini dilaksanakan di kampus Program Studi Pendidikan Dokter Gigi Universitas Sam Ratulangi, yang merupakan salah satu Program Studi di bawah naungan Fakultas Kedokteran Universitas Sam Ratulangi Manado.

Subjek yang diteliti pada penelitian ini yaitu mahasiswa angkatan 2014-2017 yang berusia $\geq 18$ tahun sebanyak 77 orang terdiri dari mahasiswa perempuan sebanyak 63 orang $(81,83 \%)$ dan mahasiwa laki-laki sebanyak 14 orang $(18,17 \%)$.

Tabel 1 menunjukkan bahwa maha- siswa berusia 19 tahun merupakan subyek terbanyak yaitu 22 orang $(28,56 \%)$ dan yang paling sedikit yaitu mahasiswa berusia 23 tahun sebanyak 1 orang $(1,3 \%)$.

Tabel 1. Distribusi subyek penelitian berdasarkan usia

\begin{tabular}{ccc}
\hline $\begin{array}{c}\text { Usia } \\
\text { (tahun) }\end{array}$ & $\mathbf{n}$ & $\%$ \\
\hline 18 & 13 & 16,89 \\
19 & 22 & 28,56 \\
20 & 18 & 23,36 \\
21 & 20 & 25,99 \\
22 & 3 & 3,9 \\
23 & 1 & 1,3 \\
Total & 77 & 100 \\
\hline
\end{tabular}

Hasil pengisian kuesioner yang diberikan pada mahasiswa PSPDG Universitas Sam Ratulangi menunjukkan bahwa semua subyek penelitian tidak sedang menggunakan obat antikonvulsan (fenitoin, dilantin, DPH), dan seluruh subyek yang berjenis kelamin perempuan memiliki siklus menstruasi teratur yaitu sebanyak 63 orang.

Untuk kebersihan mulut subyek penelitian didapatkan hasil berbeda-beda yakni terbanyak ditemukan subyek dengan frekuensi menyikat gigi 2 kali sehari sebanyak 75 orang $(97,4 \%)$, dan paling sedikit ditemukan pada frekuensi menyikat gigi 1 kali sehari sebanyak 2 orang $(2,6 \%)$, sedangkan pada frekuensi menyikat gigi 3 kali sehari tidak ditemukan.

Untuk waktu menyikat gigi paling banyak ditemukan pada subyek dengan waktu menyikat gigi saat pagi setelah sarapan dan malam sebelum tidur sebanyak 74 orang $(96 \%)$, paling sedikit ditemukan pada waktu menyikat gigi saat mandi pagi sebanyak 3 orang (4\%); tidak ditemukan subyek yang menyikat gigi pada saat mandi sore.

Berdasarkan teknik menyikat gigi pada subyek ditemukan paling banyak dengan teknik vertikal sebanyak 49 orang $(63,6 \%)$, dan paling sedikit ditemukan dengan teknik menyikat gigi secara horizontal sebanyak 11 orang $(14,3 \%)$.

Hasil pemeriksaan gingivitis dilakukan 
dengan memeriksa rongga mulut subjek penelitian dengan menggunakan alat kaca mulut, dilanjutkan dengan penentuan gingivitis berdasarkan tanda-tanda seperti adanya perubahan warna gingiva (merah atau merah kebiruan), perubahan konsistensi, perubahan klinis dan histopatologis (mudah berdarah), perubahan tekstur jaringan gingiva (halus, mengkilap, kaku), perubahan posisi gingiva (adanya lesi), perubahan kontur gingiva.

Tabel 2 menunjukkan subjek penelitian yang mengalami gingivitis sebanyak 36 orang $(46,75 \%)$ dan yang memiliki gingiva sehat sebanyak 41 orang $(53,25 \%)$.

Tabel 2. Distribusi hasil pemeriksaan gingivitis

\begin{tabular}{ccc}
\hline Gingivitis & $\mathbf{n}$ & $\mathbf{\%}$ \\
\hline Ya & 36 & 46,75 \\
Tidak & 41 & 53,25 \\
Total & 77 & 100 \\
\hline
\end{tabular}

Hasil penilaian status gizi dilakukan menggunakan rumus perhitungan IMT. Pengukuran berat badan menggunakan alat timbangan badan dan pengukuran tinggi badan menggunakan stature meter. Hasil ukurnya dikategorikan menjadi 4 kategori yaitu kurus $<18,5$; normal $\geq 18,5-<24,9$; berat badan lebih $\geq 25,0-<27,0$; dan obesitas $\geq 27,0$. Tabel 3 menampilkan bahwa status gizi yang terbanyak ditemukan yaitu kategori normal sebanyak 50 orang $(64,94 \%)$, dan yang paling sedikit yaitu kategori obesitas sebanyak 5 orang $(6,50 \%)$.

Tabel 3. Distribusi hasil penilaian status gizi

\begin{tabular}{ccc}
\hline Status gizi & $\mathbf{n}$ & $\mathbf{\%}$ \\
\hline Kurus & 15 & 19,47 \\
Normal & 50 & 64,94 \\
Berat badan & 7 & 9,09 \\
lebih & & \\
Obes & 5 & 6,50 \\
Total & 77 & 100 \\
\hline
\end{tabular}

Tabel 4 menunjukkan bahwa subjek penelitian yang mengalami gingivitis dengan status gizi tidak normal (kurus, berat badan lebih, dan obesitas) sebanyak 24 orang; kategori status gizi normal sebanyak 12 orang; sedangkan subjek penelitian yang memiliki gingiva sehat pada kategori status gizi tidak normal (kurus, berat badan lebih, dan obesitas) sebanyak 3 orang, dan kategori status gizi normal sebanyak 38 orang.

Berdasarkan hasil analisis uji statistik Chi-square ditemukan nilai $P=0,000$, yang menunjukkan adanya hubungan bermakna antara status gizi dengan gingivitis karena. Nilai Odds Ratio mendapatkan OR $=25,333(95 \% \mathrm{CI}=6,473-99,145) \quad$ berarti seseorang yang termasuk kategori status gizi tidak normal (kurus, berat badan lebih, dan obesitas) mempunyai risiko 25,333 kali lebih besar mengalami gingivitis dibandingkan dengan seseorang yang memiliki kategori status gizi normal.

Tabel 4. Hubungan antara status gizi dengan gingivitis pada mahasiwa Program Studi Pendidikan Dokter Gigi Universitas Sam Ratulangi

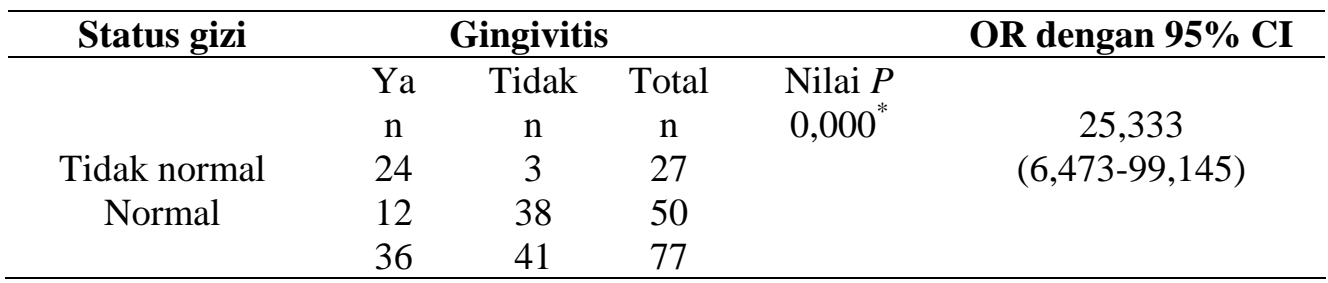

\section{BAHASAN}

Hasil penelitian berdasarkan pemeriksaan gingivitis pada subyek penelitian menunjukkan bahwa hampir seimbang pada sampel yang mengalami gingivitis sebanyak 36 orang $(46,75 \%)$ dan yang memiliki gingiva sehat sebanyak 41 orang $(53,25 \%)$. Hal ini dikarenakan adanya faktor-faktor yang memengaruhi terjadinya gingivitis yakni faktor lokal seperti 
kebersihan gigi dan mulut. Berdasarkan hasil kuesioner ditemukan hampir semua subjek penelitian telah berperilaku menyikat gigi; untuk frekuensi menyikat gigi ditemukan hampir keseluruhan sampel 2 kali sehari sebanyak 75 orang $(97,4 \%)$; untuk waktu menyikat gigi paling banyak ditemukan pada saat setelah makan pagi dan sebelum tidur malam sebanyak 74 orang (96\%); dan untuk teknik menyikat gigi lebih dominan ditemukan dengan teknik menyikat gigi secara vertikal sebanyak 49 orang $(63,6 \%)$. Hal ini sejalan dengan penelitian oleh Christiany et al. ${ }^{11}$ yang menyatakan bahwa sebagian besar mahasiswa Program Studi Pendidikan Dokter Gigi memiliki kebiasaan menyikat gigi dengan teknik menyikat gigi vertikal sebanyak 92,9\%. Teknik menyikat gigi vertikal dapat menyebabkan cedera pada jaringan periodontal. Hasil penelitian ini didukung oleh Riskesdas tahun $2013^{3}$ tentang menyikat gigi setiap hari dan berperilaku benar menyikat gigi, di Provinsi Sulawesi Utara menunjukkan bahwa hampir keseluruhan masyarakat menyikat gigi setiap hari sebanyak $95,3 \%$ namun untuk menyikat gigi dengan teknik yang benar hanya ditemukan sebanyak 3,3\%.

Berdasarkan hasil pemeriksaan gingivitis menurut jenis kelamin perempuan merupakan jumlah terbanyak yaitu dari 63 orang $(81,83 \%)$ yang mengalami gingivitis sebanyak 39,7\%. Jumlah ini empat kali lipat lebih banyak dari pada subyek lakilaki yang hanya berjumlah 14 orang $(18,17 \%)$ dengan persentase yang mengalami gingivitis sebanyak $78,6 \%$. Hal ini diduga karena perubahan hormon pada perempuan berpengaruh terhadap jaringan periodontal. Peningkatan kadar hormonal, terutama estrogen dan progesteron menyebabkan terjadinya perubahan permeabilitas kapiler dan peningkatan aliran cairan gingiva sehingga terjadinya peningkatan risiko penyakit gingiva dan penyakit periodontal pada perempuan. ${ }^{12}$

Hasil pemeriksaan gingivitis menurut usia didapatkan subyek paling banyak pada usia 19 dan 21 tahun, yang menunjukkan bahwa pada usia 19 tahun terdapat jumlah seimbang antara yang mengalami gingivitis dan yang memiliki gingiva sehat masingmasing sebanyak 11 orang $(50 \% \%)$, dan terjadi penurunan pada kategori yang mengalami gingivitis sebanyak 7 orang (35\%) pada usia 21 tahun. Hal ini mungkin dikarenakan meningkatnya kesadaran seseorang dalam menjaga kesehatan gigi dan mulut sesuai bertambahnya usia. ${ }^{13}$

Hasil penelitian yang dilakukan pada mahasiswa Program Studi Pendidikan Dokter Gigi Universitas Sam Ratulangi menunjukkan bahwa terdapat hubungan bermakna antara status gizi dengan gingivitis yang ditunjukkan oleh hasil uji chi-square dengan nilai $P=0,000<0,05$. Pada penelitian ini ditemukan mahasiswa yang mengalami gingivitis paling banyak pada kategori status gizi tidak normal yaitu kurus, berat badan lebih, dan obesitas, sebanyak 24 orang (Tabel 3). Hal ini dapat disebabkan oleh status gizi memengaruhi respon imunologi terhadap antigen bakteri yang membantu mekanisme perbaikan jaringan periodontal. Respon imunologi tentunya saling berkaitan erat dengan gizi yang cukup. Kekurangan zat gizi sangat memengaruhi ketahanan kekebalan host terhadap pertumbuhan mikroba. Respon imunologi yang berkurang dapat memperbesar peluang kolonisasi mikroba dalam rongga mulut sebagai penyebab penumpukan bakteri sehingga terbentuknya akumulasi plak yang merupakan penyebab awal terjadinya berbagai penyakit periodontal antara lain gingivitis. ${ }^{14}$

Hasil penelitian ini sejalan dengan penelitian yang dilakukan oleh Suhail dan Al-Obaidi di Iraq yang menyatakan bahwa gingivitis lebih banyak ditemukan pada kelompok yang kekurangan gizi dibandingkan dengan kelompok yang memiliki kelebihan berat badan. ${ }^{11}$ Hasil penelitian ini juga sejalan dengan penelitian yang dilakukan oleh Satria et al. ${ }^{15}$ di Kecamatan Tanete Rilau Kabupaten Barru yang menyatakan bahwa semakin mengarah ke normal berat badan seseorang akan memiliki sedikit peluang untuk mengalami gingivitis begitupun sebaliknya. Faktor penyebabnya ialah kalkulus yang banyak di 
dalam rongga mulut, faktor sosial ekonomi dan perilaku yang sering mengabaikan pentingnya menjaga kesehatan gigi dan mulut. Penelitian ini juga didukung oleh Russel et al. ${ }^{16}$ di Haiti menyatakan bahwa lebih setengah dari anak muda Haiti yang mengalami malnutrisi disertai dengan kondisi periodontal yang buruk.

Penemuan menarik pada penelitian ini menunjukkan bahwa gingivitis tidak hanya dialami pada kategori status gizi tidak normal dalam hal ini kurus, namun termasuk juga berat badan lebih dan obesitas. Hal ini sejalan dengan penelitian yang dilakukan oleh Wijaksana ${ }^{17}$ yang menyatakan bahwa jumlah jaringan adiposa berlebih pada individu obes menyebabkan tingginya kadar adipokin proinflamasi. Penyakit infeksi pada rongga mulut seperti gingivitis menyebabkan gangguan kemampuan untuk mengunyah, sehingga kemungkinan untuk mengunyah makanan berserat dan bernutrisi tergantikan oleh makanan yang lebih lembut yang mengandung karbohidrat dan asam lemak jenuh sehingga memicu obesitas. Penelitian yang dilakukan oleh Al-Rawi ${ }^{18}$ menyatakan bahwa peningkatan berat badan juga berkaitan dengan kondisi kesehatan mulut. Individu yang kelebihan berat badan memiliki peluang mengalami masalah pada jaringan periodontal seperti gingivitis. Pada studi yang dilakukan oleh Mohammed di Irak dilaporkan bahwa gingivitis ringan paling banyak terjadi pada kategori kelebihan berat badan maupun berat badan normal. ${ }^{18}$ Hal ini selaras dengan penelitian yang dilakukan oleh Kumar et al. ${ }^{19}$ di India pada subjek penelitian berusia 18-54 tahun yang menyatakan bahwa kelebihan berat badan pada orang dewasa bisa menjadi faktor risiko yang potensial untuk mengalami masalah jaringan periodontal. Juga sejalan dengan penelitian oleh Pujiastuti ${ }^{20}$ yang menunjukkan bahwa orang obes memiliki kemungkinan mengalami diabetes melitus yang merupakan etiologi sekunder sistemik terjadinya penyakit periodontal seperti gingivitis.

\section{SIMPULAN}

Berdasarkan hasil penelitian yang dilakukan di Program Studi Pendidikan Dokter Gigi Universitas Sam Ratulangi dapat disimpulkan bahwa terdapat hubungan bermakna antara status gizi dengan gingivitis. Seseorang yang termasuk kategori status gizi tidak normal (kurus, berat badan lebih, dan obesitas) mempunyai risiko 25,333 kali lebih besar mengalami gingivitis dibandingkan yang memiliki kategori status gizi normal.

\section{SARAN}

Disarankan kepada pihak Program Studi Pendidikan Dokter Gigi Universitas Sam Ratulangi agar menambah poster, pamflet dan sejenisnya tentang kesehatan gigi dan mulut di lingkungan kampus sebagai media preventif agar dapat tercipta perilaku serta kebiasaan yang baik untuk menjaga kesehatan gigi dan mulut.

Diharapkan kepada masing-masing mahasiswa untuk memeriksakan gigi minimal 6 bulan sekali guna merawat kesehatan gigi dan mulut.

\section{DAFTAR PUSTAKA}

1. Ishartono, Santoso TR. Sustainable Development Goals (SDGs) dan Pengentasan Kemiskinan. Journal Social Work. 2016;6(2):159-67.

2. Sustainable Development Goals (SDGs). UNDP. [cited 2018 March 5]. Available from: http://www.undp.org/ content/undp/en/home/sustainabledevelopment-goals.html

3. Riset Kesehatan Dasar (RISKESDAS). Status Gizi. Jakarta: Kementrian Kesehatan RI, 2014; p. 110-7, 223-6.

4. DepKes RI. Gizi Seimbang Atasi Masalah Gizi Ganda. Jakarta: Komunikasi Publik Sekretariat Jenderal Kementrian RI, 2013.

5. Makalew YM, Kawengian SES, Malonda NHS. Hubungan antara asupan energi dan zat gizi dengan status anak sekolah dasar. Manado: Program Studi Gizi Masyarakat Universitas Sam Ratulangi; 2013.

6. Sasea A, Lampus BS, Supit A. Gambaran status kebersihan rongga mulut dan status gingiva pada mahasiswa dengan 
gigi berjejal. e-G. 2013;1(1):52-8.

7. Wahyukundari MA. Perbedaan kadar matrix metalloproteinase- 8 setelah scaling dan pemberian tetrasiklin pada penderita periodontitis kronis. Jurnal PDGI; 2009;58(1):1-6.

8. Notohartojo IT, Halim FS. Gambaran kebersihan mulut dan gingivitis pada murid sekolah dasar di Puskesmas Sepatan, Kabupaten Tangerang. Media Litbang Kesehatan. 2010;20(4):180.

9. Kasiha HE, Kawengian SES, Juliatri. Gambaran tingkat pengetahuan ibu hamil tentang gingivitis di Puskesmas Kakaskasen Tomohon. eG. 2017;5( 2): 167.

10. Mashabi NA. Kaitan antara status gizi dengan gingivitis di Kecamatan Karangantu Banten. Journal of Dentistry Indonesia. 2004;11(2):59-62.

11. Christiany J, Wowor VNS, Mintjelungan CN. Pengaruh teknik menyikat gigi vertikal terhadap terjadinya resesi gingiva. eG. 2015;3(2):603-9.

12. Anggraini CW, Melok AW, Peni $P$. Gambaran status kebersihan rongga mulut dan status gingiva pasien RSGM Universitas Jember Oktober-November Tahun 2015. e-Jurnal Pustaka Kesehatan. 2016;4(3):525-32.

13. Kiswaluyo. Hubungan usia dan jenis kelamin dengan kejadian karies gigi siswa Sekolah Dasar Sumbersari dan Puger Kabupaten Jember. Jember: Fakultas Kedokteran Gigi Universitas Jember; 2010:47-54

14. Anbarasi K, Ravi BK, Sathasivasubramanian S. Gizi dan kesehatan gigi dan mulut. Asian Pacific Journal of Tropical Disease. 2012;7-8.

15. Satria A, Achmad MH, Adam AM. A cross sectional study of nutritional status among a group of school children in relation with gingivitis and dental caries severity. Journal of Dentomaxillofacial Science. 2016;1(3):150-4.

16. Russel SL, Psoter WJ, Charles GJ, Prophte S, Gebrian B. Protein-energy malnutrition during early childhood and periodontal disease in the permanent dentition of Haitian adolescents aged 12-19 years: a retrospective cohort study. Int J Paediatr Dent. 2010; 20(3): 222-9.

17. Wijaksana IKE. Infectobesity dan periodontitis: hubungan dua arah obesitas dan penyakit periodontal. Odonto Dental Journal. 2016;3(1):69-72.

18. Al-Rawi NA. Oral cleanliness and gingival health condition in relation to body mass index and certain salivary immunoglobulin among tonsillectomies children. International Journal of Scientific \& Engineering Research. 2016;7(2):1505-6.

19. Kumar S, Dagli RJ, Dhanni C, Duraiswamy $\mathbf{P}$. Relationship of body mass index with periodontal health status of Green Marble mine laborers in Kesariyaji. Braz Oral Res. 2009;23(4): 365-9.

20. Pujiastuti P. Obesitas dan penyakit periodontal. Stomatognatic (J.K.G. Unej.). 2012;9(2):82-5. 